\title{
Identifikasi tinggi badan melalui pengukuran panjang lengan bawah
}

\author{
${ }^{1}$ Tychara Korah \\ ${ }^{2}$ James F. Siwu \\ ${ }^{2}$ Johannis F. Mallo
}

\author{
${ }^{1}$ Kandidat Skripsi Fakultas Kedokteran Universitas Sam Ratulangi Manado \\ ${ }^{2}$ Bagian Ilmu Kedokteran Forensik Fakultas Kedokteran \\ Universitas Sam Ratulangi Manado \\ Email: tycharakorah1218@yahoo.com
}

\begin{abstract}
Forensic identification is the effort aimed to determine a person's identity post mortem. Height is needed in the identification process. There are formulas that that can be used in determining the height by measuring the length of certain bones. This study aimed to determine whether there was a significant relationship between height and length of forearm which is still wrapped by muscles and skin. This was a quantitative analytical study. Respondents were 50 alive individuals consisted of males and females who lived in Manado. The Pearson Correlation test showed a significant relationship between height and length of the forearm with a value of $r=0.897$. The more the length of the forearm, the more the height.

Keywords: height, forearm length
\end{abstract}

\begin{abstract}
Abstrak: Identifikasi forensik merupakan upaya yang dilakukan dengan tujuan membantu penyidik menentukan identitas seseorang untuk kepentingan visum et repertum (VeR). Tinggi badan merupakan salah satu hal yang dibutuhkan dalam proses identifikasi. Terdapat formula/rumus yang dikemukakan beberapa ahli untuk menentukan tinggi badan melalui pengukuran panjang beberapa tulang tertentu. Penelitian ini bertujuan untuk mengetahui ada tidaknya hubungan yang bermakna antara tinggi badan dengan panjang lengan bawah yang masih terbungkus oleh jaringan otot dan kulit dalam keadaan utuh. jenis penelitian ini kuantitatif analitik yang dilakukan terhadap laki-laki dan perempuan yang masih hidup khususnya yang ada di Manado. Jumlah keseluruhan responden sebanyak 50 orang. Hasil uji Pearson correlation memperlihatkan adanya hubungan bermakna antara tinggi badan dan panjang lengan bawah, dengan nilai $r=0,897$. Semakin bertambahnya panjang lengan bawah, akan diikuti dengan semakin bertambahnya tinggi badan.
\end{abstract}

Kata kunci: tinggi badan, panjang lengan bawah

Pada dasarnya prinsip identifikasi ialah membandingkan data antemortem (data semasa hidup) dan data post-mortem (data setelah kematian) pada orang yang tidak dikenal. Seiring perkembangan waktu, telah terjadi banyak kemajuan dalam ilmu kedokteran Forensik yang berkembang menjadi ilmu yang mencakup berbagai aspek ilmu pengetahuan. Dalam ilmu kedokteran Forensik identifikasi merupakan hal yang penting., ${ }^{1,2}$

Identifikasi forensik merupakan upaya yang dilakukan dengan tujuan membantu penyidik menentukan identitas seseorang untuk kepentingan visum et repertum (VeR). ${ }^{3}$ Identifikasi korban yang sudah meniggal dilakukan dengan sangat teliti untuk memperoleh identitas seperti jenis kelamin, panjang dan berat badan, suku bangsa, warna kulit, keadaan rambut, mata, gigi, berkas luka, dan sebagainya.,4

Dari berbagai data yang diperoleh penulis baik dari media cetak maupun elektronik, sampai dengan bulan Mei tahun 
2015 masih tercatat adanya kasus mutilasi yang terjadi di Indonesia, khususnya daerah Sulawesi Utara. Proses identifikasi dibutuhkan oleh penyidik untuk mengungkap identitas korban akibat mutilasi, juga untuk mengonfirmasi adanya formula/rumus yang telah ditemukan beberapa ahli untuk menentukan panjang badan melalui panjang beberapa tulang karena salah satu identifikasi yang diperlukan ialah memperkirakan panjang badan korban yang berguna untuk memudahkan proses identifikasi. ${ }^{5}$

Dalam kasus mutilasi, selain jari-jari tangan/telapak tangan, kepala juga menjadi bagian yang paling sering menjadi incaran pelaku kejahatan untuk dihilangkan, dimana hal tersebut dilakukan untuk menghilangkan identitas korban. ${ }^{6,7}$

Beberapa cara memisahkan bagian tubuh yang sering terjadi pada kasus mutilasi ialah dengan memisahkan kepala pada leher, memisahkan tangan pada daerah ketiak, siku ataupun pergelangan tangan, memisahkan kaki pada daerah paha atau lutut. $^{8}$

\section{METODE PENELITIAN}

Jenis penelitian ialah kuantitatif analitik dengan desain potong lintang yang bertujuan untuk membuktikan ada tidaknya hubungan yang signifikan antara panjang lengan bawah kanan dan kiri dengan tinggi badan.

\section{HASIL PENELITIAN}

Hasil penelitian perkiraan tinggi badan melalui panjang lengan bawah ini dilakukan terhadap 50 orang (25 laki-laki orang dan 25 orang perempuan) dalam periode bulan November 2015 sampai dengan Desember 2015. Data ditampilkan dalam bentuk tabel dengan kolom isian: nama, usia (tahun), suku, jenis kelamin, suku, tinggi badan (cm), dan panjang lengan bawah $(\mathrm{cm})$.

Data yang diperoleh merupakan data parametrik dari hasil uji normalitas shapirowilk dengan SPSS. Data kemudian diolah dengan uji korelasi Pearson untuk menemukan ada tidaknya hubungan yang bermakna antara panjang lengan bawah dengan tinggi.

Dari Tabel 1 didapatkan tinggi badan (TB) minimum $151 \mathrm{~cm}$ dan maksimum 173 cm; panjang lengan bawah (PLB) kanan minimum $19 \mathrm{~cm}$ dan maksimum $31 \mathrm{~cm}$; serta panjang lengan bawah kiri minimum $19 \mathrm{~cm}$ dan maksimum $31 \mathrm{~cm}$.

Tabel 1. Sebaran Responden Menurut Ukuran Tinggi Badan Dan Panjang Lengan Bawah Kanan Dan Kiri

\begin{tabular}{lllll}
\hline Variabel & N & Maks & Min & Mean \\
\hline TB & 50 & 173 & 151 & 162,56 \\
PLB Ka & 50 & 31 & 19 & 24,56 \\
PLB Ki & 50 & 31 & 19 & 24,56 \\
\hline
\end{tabular}

TB : tinggi badan

PLB : panjang lengan bawah kanan/kiri

Dari Tabel 2 didapatkan adanya hubungan bermakna antara PLB dengan TB pada 50 responden dengan nilai $r=0,897$

Tabel 2. Analisa Hubungan Panjang Lengan Bawah Kanan Dengan Tinggi Badan Pada Seluruh Responden

\begin{tabular}{llll}
\hline Variabel & $\begin{array}{l}\text { Pearson } \\
\text { correlation (r) }\end{array}$ & N & P \\
\hline $\begin{array}{l}\text { Lengan } \\
\text { bawah kanan } \\
\text { dengan }\end{array}$ & 0,897 & 50 & 0,0001 \\
tinggi badan & & & \\
\hline
\end{tabular}

Dari Tabel 3 didapatkan adanya hubungan bermakna antara panjang lengan bawah dengan tinggi badan pada 50 responden dengan nilai $r=0,897$.

Tabel 3. Analisis Hubungan Panjang Lengan Bawah Kiri Dengan Tinggi Badan Pada Seluruh Responden

\begin{tabular}{llll}
\hline Variabel & $\begin{array}{c}\text { Pearson } \\
\text { correlation (r) }\end{array}$ & $\mathrm{N}$ & $\mathrm{P}$ \\
\hline $\begin{array}{l}\text { Lengan } \\
\text { bawah kanan } \\
\text { dengan } \\
\text { tinggi badan }\end{array}$ & & 50,897 & 0,0001 \\
\hline
\end{tabular}




\section{BAHASAN}

Penelitian yang dilakukan terhadap 50 orang responden (25 laki-laki orang dan 25 orang perempuan) secara umum memiliki panjang lengan bawah kanan dan kiri yang sama yang menunjukkan bahwa pengaruh panjang lengan bawah kanan yang lebih dari kiri tidak memiliki pengaruh pada hasil analisis data.

Seluruh responden termasuk pengguna tangan kanan dan ditemukan tinggi badan yang sama tetapi panjang lengan bawah tidak sama, juga panjang lengan bawah yang sama tetapi tinggi badan tidak sama namun tidak didapatkan pengaruh yang bermakna dalam hasil analisis data.

Uji korelasi data tinggi badan minimum $153 \mathrm{~cm}$, dan maksimum $177 \mathrm{~cm}$ dan panjang lengan bawah minimum 23,2 $\mathrm{cm}$, dan maksimum 32,6 cm menunjukkan adanya hubungan bermakna antara panjang lengan bawah dengan tinggi badan pada 50 responden dengan nilai $\mathrm{r}=0,897$.

Analisis data menggunakan uji Pearson Correlation karena data yang diperoleh merupakan statistik parametrik untuk mengetahui ada tidaknya hubungan antara panjang lengan bawah kanan dan kiri dengan tinggi badan. Terdapat hubungan yang signifikan antara panjang lengan bawah kanan dan kiri terhadap tinggi badan baik laki-laki maupun perempuan.

\section{SIMPULAN}

Dari hasil penelitian dan bahasan dapat disimpulkan bahwa terdapat hubungan bermakna antara panjang lengan bawah kanan dan kiri dengan tinggi badan pada laki-laki dan perempuan.

\section{SARAN}

Perlu dilakukan penelitian lanjut untuk berbagai kelompok usia, suku, dan ras yang ada di Indonesia.

\section{UCAPAN TERIMA KASIH}

Ucapan Terima Kasih disampaikan kepada dr. Djemi Tomuka SH, MH, DFM serta semua pihak yang baik secara langsung maupun tidak langsung telah menumbuhkan ide atau gagasan dalam pemikiran penulis.

\section{DAFTAR PUSTAKA}

1. Hamdani N. Identifikasi Mayat. In: Ilmu Kedokteran Kehakiman (2nd ed). Jakarta: Gramedia Pustaka Utama, 1992; p. 83-8.

2. Wiliam DJ, Ansford AJ, Friday DS. Identification. In: Colour Guide Forensic Pathology. New York: Churchill Livingstone, 2002; p. 1320.

3. Amir A. Identifikasi. In: Rangkaian Ilmu Kedokteran Forensik (2nd ed). Medan: Bagian Ilmu Kedokteran Forensik FK-USU, 2005; p. 178-203.

4. Franklin CA. Postmortem Examination (Autopsy). In: Modi's Textbook of Medical Jurisprudence and Toxicology (21 ed). Bombay: Tripathi Private Limited, 1988; p. 6995.

5. Nandy A. Identification of an Individual. In: Principles of Forensic Medicine. Calcutta: New Central Book Agency (P) Ltd., 1996; p. 47- 53.

6. Camps FE. Identification by the Skeletal Structures. Postmortem incised wound and mutilation. In: Gradwohl's Legal Medicine (3rd ed). Chicago: A John Wright \& Sons Ltd. Publication, 1976; p. 109-11.

7. Knight B. The Establishment of Identity of Human Remains. In: Forensic Pathology (2nd ed). New York: Oxford University Press, 1996; p. 95130.

8. Parikh CK. Medicolegal Postmortem in India. Bombay: Medical Publications, 1985; p. 1-15. 